\title{
BACTERIAL FILTERS - ARE THEY NECESSARY ON ANAESTHETIC MACHINES?
}

\author{
F.C. Ping, J.L. OULton, J.A. SMith, A.G. SKIDMORE AND L.C. JENKINS
}

\begin{abstract}
ANAESTHETIC EQUIPMENT is prone to colonization by bacteria. ${ }^{1-8}$ Cultures have yielded growth from face masks. airways. tracheal tubes, corrugated breathing tubes and reservoir bags. Even the soda lime cannister may be contaminated. Thomas $^{10}$ has compiled an extensive list of pathogenic and non-pathogenic organisms that may be isolated.

Transmission of bacteria from unclean ventilators has been reported ${ }^{11-14}$ and has occasionally resulted in death in susceptible patients. The need for clean anaesthetic equipment is therefore apparent. Bacterial filters have been recommended as one method of reducing cross contamination from anaesthetic equipment. ${ }^{10.11 .15} \mathrm{At}$ the Vancouver General Hospital the vast inventory of anaesthetic equipment required for its 38 operating rooms has made it necessary to have a decontamination system that is fast, efficient and economical. This investigation was conducted to study anaesthetic equipment as used in our hospital and to judge whether the procedure was safe based on bacterial culturing. In particular we wished to know whether bacterial filters would likely to add to the safety of our procedure.
\end{abstract}

\section{Methods}

Cleaning and handling of anciesthetic equipment Disposable tracheal tubes are used. Between cases. face masks, airways, corrugated breathing tubes, Y-piece connectors, elbow connectors. reservoir bags and suction catheters are removed by anaesthetic aides. All these except suction catheters are machine washed* for forty minutes in hot tap water. Following this, they are pasteurized $\dagger$ at $82.2^{\circ} \mathrm{C}\left(180^{\circ} \mathrm{F}\right)$ for another twenty minutes and then hung to dry. Suction catheters are rinsed and flushed through with hot tap water.

F.C. Ping. M.B..Ch.B., B.A.O.; J.L. Outton. M.D., C.M. F.R.C.P.(C); J.A. Smith, M.D., F.R.C.P.(C); A.G. Skidmore. M.D., F.R.C.P.(C); and L.C. Jenkins. M.D. C.M.. F.R.C.P.(C). Department of Anaesthesia and Division of Microbiology, University of British Columbia and Vancouver General Hospital, Vancouver, B.C.

* Pasteumatic Washer. Olympic Medal.

†Pasteumatic, Olympic Medal.

Canad. Anaesth. Soc. J.. vol. 26, no. 5. September 1979 visually checked and then hung to dry. Following this they are wrapped and autoclaved. Laryngoscope blades are washed with four per cent isopropyl alcohol. Laryngoscope handles are wiped with 70 per cent alcohol.

Between uses, face masks, airways. tracheal tubes, elbow connectors and suction catheters are stored in the drawers of the anaesthetic carts. Corrugated tubes are attached to $Y$-piece connectors and hung with the reservoir bags on racks in the anaesthetic room.

Before starting each case, clean equipment is attached to the anaesthetic machines by the anaesthetist.

At the end of the day, the anaesthetic machine and the domes of the valve housing are wiped with 70 per cent isopropyl alcohol.

The corrugated tubing between the ventilator and the carbon dioxide cannister is changed daily. Once each week the assister-controller (Bird Mark IV) is dismantled; all removable parts are machine-washed and pasteurized. The lower part of the outer casing is soaked in 20 per cent chlorhexidine. Non-immersible parts are wiped with 70 per cent alcohol. Soda lime is changed whenever the indicator colour suggests that it is necessary.

\section{Patient population}

The study population consisted of two groups. Group I was made up of 18 males and 15 females, none of whom had clinical symptoms of respiratory tract disease. Group II consisted of 12 men and five women all of whom had excessive lower respiratory tract secretions. Sixteen patients in Group II had chronic bronchitis and one woman had cystic fibrosis. Ages ranged between 14 and 84 years with a mean of 52 years. All patients fell within ASA classification I, II or III. ${ }^{17}$

\section{Anaesthetic equipment and techniques}

Throughout this study the same four anaesthetic machines were used in their respective operating rooms. They were Boyle machines with Mark III or Mark IV absorber heads. They carried Mark VIII Bird ventilators and Mark IV assister controllers. Various anaesthetists were involved. The anaesthetic was either nitrous 415 
TABLE 1

Patient Population

\begin{tabular}{|c|c|c|c|c|c|c|c|c|c|c|c|c|}
\hline \multirow{2}{*}{$\begin{array}{c}\text { Patient } \\
\text { classification }\end{array}$} & \multirow[b]{2}{*}{$\mathbf{M}$} & \multirow[b]{2}{*}{$\mathbf{F}$} & \multirow[b]{2}{*}{ Age Range (yrs) } & \multicolumn{5}{|c|}{ ASA status } & \multicolumn{4}{|c|}{ Anaesthesia times (mins) } \\
\hline & & & & 1 & 2 & 3 & 4 & 5 & $\leq 60$ & $>60-120$ & $>120-180$ & $>180$ \\
\hline Group I & 18 & 15 & 15-84 (Mean - 50) & 11 & 12 & 10 & 0 & 0 & 6 & 14 & 7 & 6 \\
\hline Group II & 12 & 5 & $14-75($ Mean - 56) & 0 & 8 & 9 & 0 & 0 & 1 & 8 & 6 & 2 \\
\hline
\end{tabular}
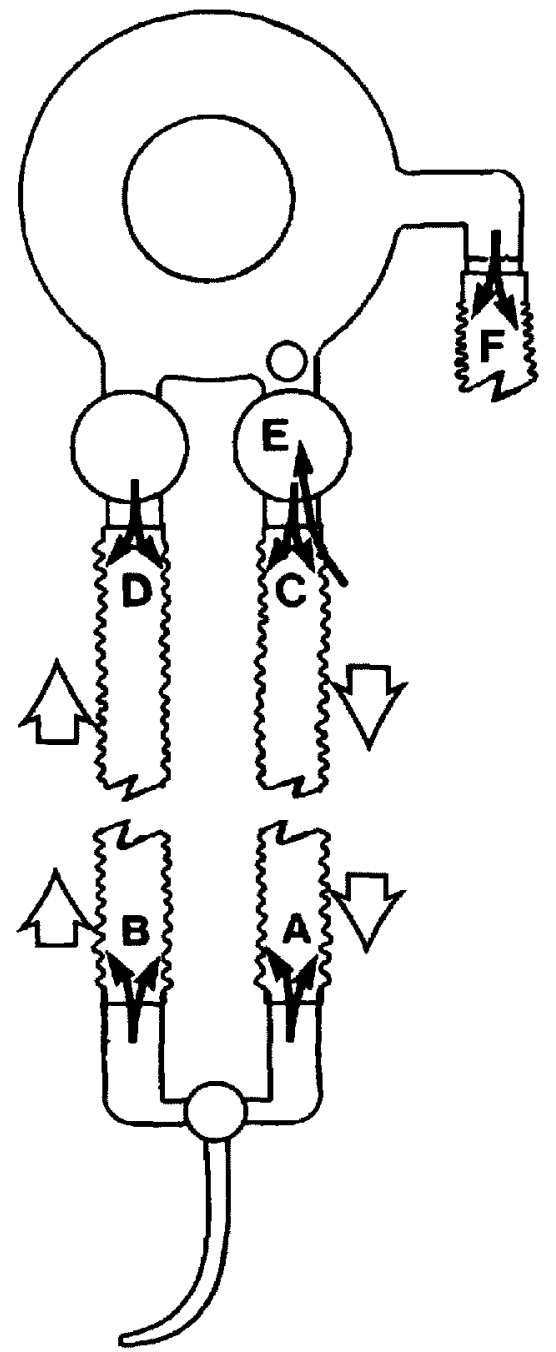

Figure 1 Open arrows indicate director of gas flow. Solid arrows indicate sampling sites. A-D. Interior of corrugated breathing tubes at patient end and machine end. $E$, Interior of inspiratory valve housing. $F$, Interior of ventilator corrugated tubing at absorber end. oxide-narcotic or nitrous oxide-halothane-narcotic. The trachea was intubated orally under direct vision in all instances. Controlled ventilation was used in most cases. Duration of anaesthesia ranged from 30 minutes to 420 minutes with a mean of 129 minutes.

\section{Bacteriological sampling}

The sites from which swabs were taken immediately before and after anaesthesia are indicated in Figure 1.

Five circular motions with a sterile dry cotton swab were applied to each wet sampling area and. where sites were dry, the swab was premoistened with sterile normal saline. Blood agar plates were inoculated immediately by rotating the swab on the surface of the agar and the inoculum was streaked in the standard fashion. Plates were incubated aerobically at $37^{\circ} \mathrm{C}$; none were incubated anaerobically.

Lower respiratory tract secretions were sampled from Group II patients by tracheal suction immediately after intubation using a sterile catheter. These samples were inoculated on blood agar plates aerobically at $37^{\circ} \mathrm{C}$.

Bacterial isolates were identified using standard methods.

\section{Results}

Characteristics of the patients studied are shown in Table I.

Of 550 cultures taken from the anaesthetic equipment only five yielded growth. Staphy. lococcus epidermidis occurred in four cultures and streptococcus viridans in one. These were from three patients (Table II).

Tracheal specimens cultured from Group II patients yielded the following growth: streptococcus viridans. This was isolated at postanaesthetic site $B$ following 165 minutes of anaesthesia administered to a 14-year-old girl with cystic fibrosis; her post-induction tracheal specimen grew staphylococcus aureus. In one patient in whom streptococcus viridans was cul- 


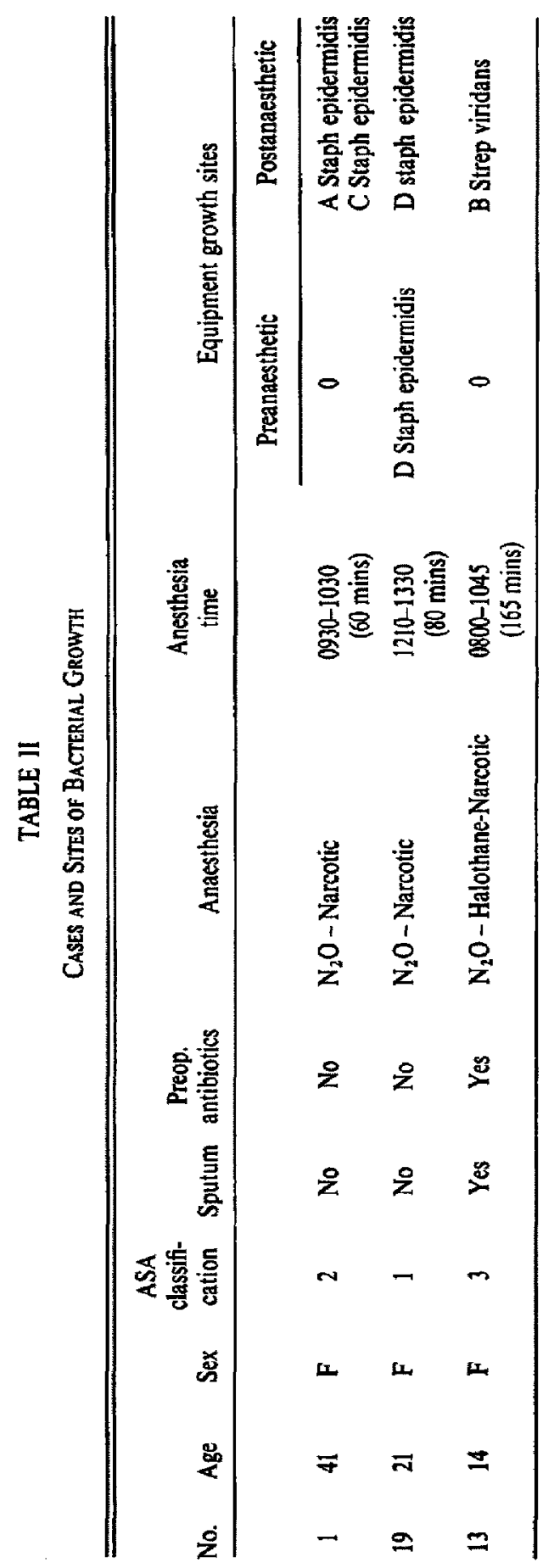


tured from the trachea, anaesthesia lasted seven hours but post-anaesthetic sites showed no growth.

\section{Discussion}

An initial attempt was made to sample sites in a quantitative fashion using sterile bacteriological loops. However, technical problems and lack of a watery medium at most sites required the use of a sampling technique similar to that used for surfaces in environmental monitoring. All cultures were taken by one individual (F.P.), thus ensuring a standard technique.

A rinse-through method of sampling was not used because this method would not necessarily rinse bacteria off the wall of the tube. Moreover, we wished segmental sampling, which would not be possible by rinse-through.

The low rate of bacterial contamination would suggest that pasteurization is an efficient method of decontamination. The isolates of staphylococcus epidermidis may have been due to an oropharyngeal source of contamination. However. we feel that an equally likely source was the anaesthetist's hands. The streptococcus viridans isolated from the expiratory valve tubing close to the patient's airway probably came from the patient's mouth.

Because of the absence of pathogens and the low rate of isolation of non-pathogenic bacteria we did not feel it necessary to extent the study beyond the 50 cases reported here.

Before this study it had been our policy to use disposable anaesthetic circuits on patients with lower respiratory tract colonization or infection. More recently bacterial filters were being used on such patients. as recommended by some workers. ${ }^{10.11 .15}$ The cost of these bacterial filters and a recent article by Mouline and Saubermann ${ }^{77}$ prompted a review of our method of decontaminating anaesthetic equipment and an assessment of the degree of risk associated with re-use of anaesthetic circuits.

Given the low rate of contamination of equipment, even after two hours of use on patients whose sputum yielded potential pathogens we concluded that the use of bacterial filters is unnecessary in our institution when a strict regimen of cleaning and pasteurization of equipment is followed.

\section{SUMMARY}

At the Vancouver General Hospital the effectiveness of the system for decontamination of anaesthetic equipment was evaluated to determine the need for bacterial filters on anaesthetic machines.

Two groups of patients were studied. Group I consisted of 33 patients, none of whom had clinical symptoms of respiratory tract disease. Group II consisted of 17 patients who had lower respiratory tract secretions. In the latter group 16 had chronic bronchitis and one had cystic fibrosis.

Of 550 bacterial cultures taken from the anaesthetic equipment immediately before and after anaesthesia in our $\mathbf{5 0}$ patients. only five yielded a growth of non-pathogenic bacteria.

The results of this study indicate that bacterial colonization of anaesthetic equipment is of a low order and is adequately controlled by pasteurization even after use in patients with chronic lower respiratory tract disease. The use of bacterial filters does not appear justified if a strict regimen of cleaning and pasteurization is followed.

\section{RÉSUMÉ}

A l'hôpital Vancouver General. l'efficacité du système de décontamination de l'appareillage a été étudié en vue d'évaluer l'utilisation des filtres antibactériens sur les appareils d'anesthésie.

L'étude a porté sur deux groupes de patients. Le premier comprenait trente-trois sujets tous libres de symptômes respiratoires et le second dix sept malades respiratories dont seize souffraient de bronchite chronique et un de fibrose kystique.

Des 550 cultures bactériennes prélevées sur l'appareillage immédiatement avant et après l'anesthésie des cinquante patients. seulement cinq ont présenté une croissance de bactéries non pathogènes.

Les résultats de cette étude montrent que la croissance de colonies bactériennes sur l'appareillage anesthésique est minime et peut ètre contrôlée facilement par pasteurisation méme après contact avec les malades souffrant de maladies chroniques des voies aériennes inféricures. L'usage de filtres antibactériens ne semble pas justifié si on adhère à un régime strict de nettoyage et de pasteurisation.

\section{REFERENCES}

1. JoSEPH. M.J. Disease transmission by inefficiently sanitized anesthetizing apparatus. J.A.M.A. 149: 1196(1952).

2. Gross, G.L. Decontamination of anesthesia apparatus. Anesthesiology 16: 903 (1955). 
3. ZiEGler. C. \& JaCoBy, J. Anesthetic equipment as a source of infection. Anesth. Analg. 35: 451 (1956).

4. JENKINS, J.R.E. \& EDGER. W.M. Sterilization of anaesthetic equipment. Anaesthesia $19: 177$ (1962).

5. Meeks, C. H. Pendleton, W.E. \& Hench, M.E. Sterilization of anesthesia apparatus. J.A.M.A. 199: $276(1967)$

6. DRYDEN. G.E. Questionnaire study of anesthesia equipment sterility. J.A.M.A. 206: 2524 (1968).

7. DRYDEN. G.E. Anesthesia equipment sterility repeat of questionnaire. Anesth. Analg. 52: 167 (1973).

8. Pandit, S.K., Mehta, S. \& Agarwal. S.C. Risk of cross-infection from inhalation anaesthetic equipment. Brit. J. Anaesth. 39: 838 (1967).

9. STRATFORD, B.C., ClaRK, R.R. \& DixON, S. The disinfection of anaesthetic apparatus. Brit. J. Anaesth. 34: 471 (1964).

10. Thomas, E.T. The problem in practice. International anesthesiology clinics. Volume $10(2), 11$ (1972).

11. Phillips, I. \& Spencer, G. Pseudomonas aeruginosa cross-infection. Lancet $2: 1325$ (1965).
12. Tinne, J.E., Gokdon, A.M.. Bain, W.H. \& MACKAY. W.A. Cross-infection by pseudomonas aeruginosa as a hazard of intensive Surgery. Brit. Med. J. 4: 313 (1967).

13. Fierer, J., TaYlór. P.M. \& Gezon, H.M. Pseudomonas aeruginosa epidemic laced 10 delivery-room resuscitators. N.E.J.M. 276: 991 (1967).

14. ATIK. M. \& Hanson, B. Gram-negative penumonitus: a new postoperative menace. American Surgeon 36: 198 (1970).

15. Shrotami, G.M., Nicholas, P.. Ballinger. C.M. \& SHAw. L. Prevention of contamination of the circle system and ventilators with a new disposable filter. Anesth. Analg. 50: 844 (1971).

16. Drirrs. R.D. ECKENHOFF, J.E. \& VANDAM, L.D. Introduction to anesthesia. 4th Ed. W.B. Saunders Co. (1972).

17. Moulin, G.C. \& SaubermanN, A.J. The anesthesia machine and circle system are not likely to be sources of bacterial contamination. Anesthesiology 47: 353 (1977). 